\title{
Vagrant Antarctic fur seals at Gough Island in 2009
}

\author{
Marthán N. Bester $\cdot$ R. R. Reisinger
}

Received: 18 October 2009 / Revised: 11 November 2009 / Accepted: 11 November 2009

(C) Springer-Verlag 2009

\begin{abstract}
The Antarctic fur seal Arctocephalus gazella at Gough Island $\left(40^{\circ} 20^{\prime} \mathrm{S}, 09^{\circ} 54^{\prime} \mathrm{W}\right)$ in the South Atlantic Ocean, first seen in October/November 2005, was recorded again in September-October 2009. Up to three different individual Antarctic fur seals were sighted on a single day, on a particular beach. A total of seven different individuals were recorded over a 3-week period, well before the onset of the breeding (pupping) season of the resident population of Subantarctic fur seals A. tropicalis. Positively identified individuals were all male, mostly subadult and lean. Only a fraction $(\sim 20 \%)$ of the available beaches was searched, and it is unknown if the Antarctic fur seals were still present at Gough Island during the austral summer breeding season of southern fur seals.
\end{abstract}

Keywords Antarctic fur seals · Gough Island ·

Subantarctic fur seals $\cdot$ South Atlantic Ocean

Over a period of 3 weeks, between 12 September and 4 October 2009, an estimated seven Antarctic fur seals Arctocephalus gazella hauled out on Gough Island $\left(40^{\circ} 20^{\prime} \mathrm{S}\right.$, $09^{\circ} 54^{\prime} \mathrm{W}$ ), the site (Fig. 1) of the largest Subantarctic fur seal breeding population in the Southern Ocean (Bester et al. 2006). Previously (6 October to 23 November 2005), an estimated 18 Antarctic fur seals Arctocephalus gazella, were hauled out here (Wilson et al. 2006). In both cases they were found on largely open boulder beaches on the leeward east coast of the island. The two species were

M. N. Bester $(\square) \cdot$ R. R. Reisinger

Department of Zoology and Entomology,

Mammal Research Institute, University of Pretoria,

Pretoria 0002, South Africa

e-mail: mnbester@zoology.up.ac.za separated following Condy (1978) and St. Clair Hill et al. (2001).

One lean subadult male Antarctic fur seal was first seen on 12 September 2009 at Seal Beach (Fig. 1) close to the Meteorological Station on the island. It was later joined by an adult male (by 25 September) and a subadult of unknown sex (on 26 September). A different subadult male (Fig. 2a) with abrasions on its nose was sighted at Cave Beach further down the coast on 18 September (Table 1). They appeared lethargic and lean, and the Cave Beach individual was largely unresponsive to very close approaches (within $1 \mathrm{~m}$ ) when we ascertained the sex of the animal. None were seen on the established breeding colony beach at Waterfall Cove and on adjacent beaches on 23 September and from close inshore (viewed from a semi-rigid inflatable) on the open boulder beaches from Luff Point to the inner reaches of Quest Bay on 28 September (Fig. 1). On the same day, a census of the small southern elephant seal Mirounga leonina population, situated on the north-eastern section (Hawkins Bay) of the leeward east coast, located an adult male Antarctic fur seal (Fig. 2b) in fair condition at Wild Glen (Fig. 1). During the following days another adult male and a subadult male hauled out here (Table 1), but by 2 October only one adult male remained.

It is impossible to say whether any of the recorded Antarctic fur seals, and indeed any other unsighted ones that might have hauled out on beaches remote from the Meteorological Station, remained ashore for the Subantarctic fur seal breeding season (Wilson et al. 2006; this study). Both fur seals have similar annual cycles, differing mainly in the duration of lactation (4 months and 10-11 months in Antarctic fur seals and Subantarctic fur seals, respectively) and median birthdates (6 December and 10 December, respectively) at sites in the Southern Atlantic Ocean (McCann and 
Fig. 1 Map of Gough Island, South Atlantic Ocean, showing the major locations on the south Gough Island's position in relation to South America, Africa and Antarctica and east coasts. The insert shows
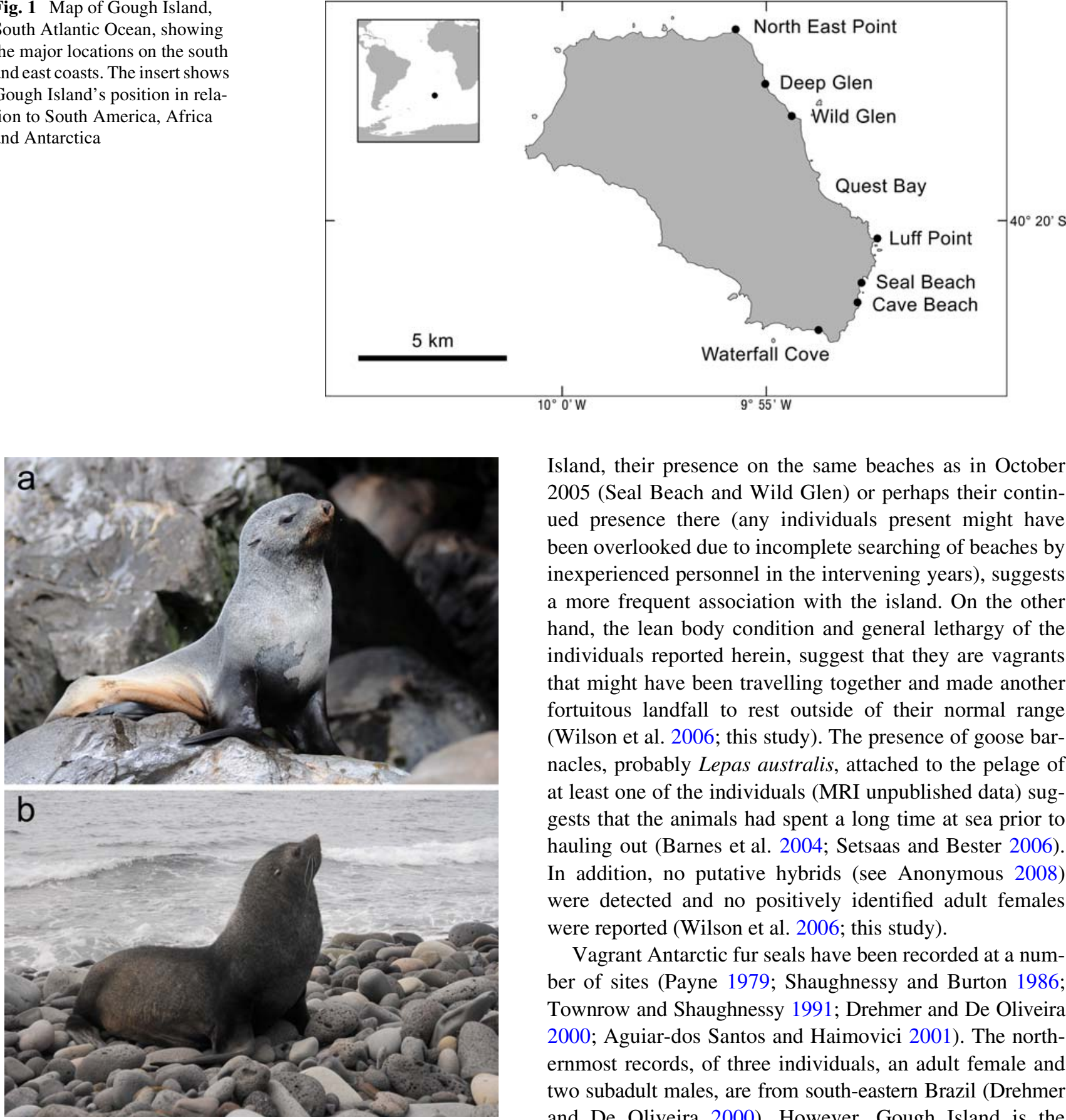

Fig. 2 Antarctic fur seals seen at Gough Island: a subadult male Antarctic fur seal at Cave Beach, b adult male Antarctic fur seal at Wild Glen (photos R. R. Reisinger)

Doidge 1987; Bester 1987). Where they breed in sympatry at, for example, Marion Island, the two species thrive and hybridize to an extent (Condy 1978; Hofmeyr et al. 2006); development of a similar situation at Gough Island would compromise the 'pure' genetic status of the Subantarctic fur seal population there (Wynen et al. 2000; Wilson et al. 2006). The re-appearance of Antarctic fur seals at Gough
Island, their presence on the same beaches as in October 2005 (Seal Beach and Wild Glen) or perhaps their continued presence there (any individuals present might have been overlooked due to incomplete searching of beaches by inexperienced personnel in the intervening years), suggests a more frequent association with the island. On the other hand, the lean body condition and general lethargy of the individuals reported herein, suggest that they are vagrants that might have been travelling together and made another fortuitous landfall to rest outside of their normal range (Wilson et al. 2006; this study). The presence of goose barnacles, probably Lepas australis, attached to the pelage of at least one of the individuals (MRI unpublished data) suggests that the animals had spent a long time at sea prior to hauling out (Barnes et al. 2004; Setsaas and Bester 2006). In addition, no putative hybrids (see Anonymous 2008) were detected and no positively identified adult females were reported (Wilson et al. 2006; this study).

Vagrant Antarctic fur seals have been recorded at a number of sites (Payne 1979; Shaughnessy and Burton 1986; Townrow and Shaughnessy 1991; Drehmer and De Oliveira 2000; Aguiar-dos Santos and Haimovici 2001). The northernmost records, of three individuals, an adult female and two subadult males, are from south-eastern Brazil (Drehmer and De Oliveira 2000). However, Gough Island is the northernmost island record of vagrant Antarctic fur seals which required open ocean navigation all the way (Wilson et al. 2006). Such records might indicate that $A$. gazella disperse from their natal breeding localities as populations recover after large-scale harvesting of the nineteen and early twentieth century ceased and congested conditions develop (McCann and Doidge 1987; Hofmeyr et al. 2005; Wilson et al. 2006).

It seems unlikely that the genetic status of the very large Subantarctic fur seal population at Gough Island (Bester et al. 2006) will be compromised by possible incursions of 
Table 1 Location, date, age class and sex, numbers and condition of Antarctic fur seals recorded on Gough Island between 12 September 2009 and 2 October 2009

\begin{tabular}{lllll}
\hline Locality & Date & Age class and sex & Number & Condition \\
\hline Seal Beach & $12 / 09 / 2009$ & Subadult male & 1 & Lean, fair \\
Seal Beach & $13 / 09 / 2009$ & Subadult male $^{\mathrm{a}}$ & 1 & Lean, fair \\
Seal Beach & $15 / 09 / 2009$ & Subadult male $^{\mathrm{a}}$ & 1 & Lean, fair \\
Seal Beach & $18 / 09 / 2009$ & Subadult male $^{\mathrm{a}}$ & 1 & Lean, fair \\
Cave Beach & $18 / 09 / 2009$ & Subadult male & 1 & Lean, lethargic, \\
& & & & abrasions on nose \\
Seal Beach & $25 / 09 / 2009$ & Adult male $^{\mathrm{a}}$ & 1 & Lean, fair \\
& & Subadult male $^{\mathrm{a}}$ & 1 & Lean, fair \\
Seal Beach & $26 / 09 / 2009$ & Adult male $^{\mathrm{a}}$ & 1 & Lean, fair \\
& & Subadult male $^{\mathrm{a}}$ & 1 & Lean, fair \\
Wild Glen & $28 / 09 / 2009$ & Subadult unid. & 1 & Poor, lethargic \\
Wild Glen & $29 / 09 / 2009$ & Adult male $^{\mathrm{a}}$ & 1 & Lean, fair \\
& & Adult male $^{\mathrm{a}}$ & 2 & Lean, fair, lethargic \\
Wild Glen & $30 / 09 / 2009-02 / 10 / 2009$ & Subadult male & 1 & Lean, fair \\
\hline
\end{tabular}

${ }^{\text {a }}$ Repeated sightings of individuals recorded previously at a particular beach
Drehmer CJ, De Oliveira LR (2000) Syncranial osteology of Arctocephalus gazella (Pinnipedia, Otariidae) from Rio Grande do Sul, Brazil. Iheringia Ser Zool 88:51-59

Hofmeyr GJG, Krafft BA, Kirkman SP, Bester MN, Lydersen C, Kovacs KM (2005) Population change of Antarctic fur seals at Bouvetøya. Polar Biol 28:725-731

Hofmeyr GJG, Bester MN, Makhado AB, Pistorius PA (2006) Population changes in Subantarctic and Antarctic fur seals at Marion Island. S Afr J Wildl Res 36:55-68

Lancaster ML, Gemmell NJ, Negro S, Goldsworthy SD, Sunnucks P (2006) Ménage à trios on Macquarie Island: hybridization among three species of fur seal (Arctocephalus spp.) following historical population extinction. Mol Ecol 15:3681-3692

Acknowledgments Logistical support at Gough Island was provided by the South African Department of Environmental Affairs through the South African National Antarctic Programme. Research at Gough Island is conducted with the permission of the Administrator and Island Council of Tristan da Cunha. Trevor Glass, Head of Tristan Conservation Department, and his assistant, Norman Glass, are thanked for their encouragement.

\section{References}

Aguiar-Dos Santos R, Haimovici M (2001) Cephalopods in the diet of marine mammals stranded or incidentally caught along southeastern and southern Brazil $\left(21-34^{\circ} \mathrm{S}\right)$. Fish Res 52:99-112

Anonymous (2008) Note on hybrid southern fur seals genus Arctocephalus. In: Jefferson TA, Webber MA, Pitman RL (eds) Marine mammals of the world: a comprehensive guide to their identification-pinnipeds, chap 5. Elsevier, USA, pp 340-341

Barnes DKA, Warren NL, Webb K, Phalan B, Reid K (2004) Polar pedunculate barnacles piggy-back on pycnogona, penguins, pinniped seals and plastics. Mar Ecol Prog Ser 284:305-310

Bester MN (1987) Subantarctic fur seal Arctocephalus tropicalis at Gough Island (Tristan da Cunha Group). In: Croxall JP, Gentry RL (eds) Status, biology and ecology of fur seals. NOAA Tech Rep NMFS 51:57-60

Bester MN, Wilson JW, Burle M-H, Hofmeyr GJG (2006) Population trend of Subantarctic fur seals at Gough Island. S Afr J Wildl Res 36:191-194

Condy PR (1978) Distribution, abundance and annual cycle of fur seals (Arctocephalus spp.) on the Prince Edward Islands. S Afr J Wildl Res 8:159-168
Lancaster ML, Bradshaw CJA, Goldsworthy SD, Sunnucks P (2007) Lower reproductive success in hybrid fur seal males indicates fitness costs to hybridization. Mol Ecol 16:3187-3197

McCann S, Doidge B (1987) Antarctic fur seal, Arctocephalus gazella. In: Croxall JP, Gentry RL (eds) Status, biology and ecology of fur seals. NOAA Tech Rep NMFS 51:5-8

Payne MR (1979) Fur seals Arctocephalus tropicalis and A. gazella crossing the Antarctic Convergence at South Georgia. Mammalia 43:93-98

Setsaas TH, Bester MN (2006) Goose barnacle (Lepas australis) infestation of the Subantarctic fur seal (Arctocephalus tropicalis). Afr Zool 41:305-307

Shaughnessy PD, Burton HR (1986) Fur seals Arctocephalus spp. at Mawson Station, Antarctica, and in the Southern Ocean. Polar Rec 23:79-81

St. Clair Hill M, Ferguson JWH, Bester MN, Kerley GIH (2001) Preliminary comparison of calls of the hybridising fur seals, Arctocephalus tropicalis and A. gazella. Afr Zool 36:45-53

Townrow K, Shaughnessy PD (1991) Fur seal skull from sealers' quarters at Sandy Bay, Macquarie Island, Southern Ocean. Polar Rec 27:245-248

Wilson JW, Burle M-H, Bester MN (2006) Vagrant Antarctic pinnipeds at Gough Island. Polar Biol 29:905-908

Wynen LP, Goldsworthy SD, Guinet C, Bester MN, Boyd IL, Gjertz I, Hofmeyr GJG, White RWG, Slade R (2000) Postsealing genetic variation and population structure of two species of fur seal (Arctocephalus gazella and A. tropicalis). Mol Ecol 9:299-314 